\title{
TRANSITIONAL JUSTICE: THE REINTEGRATION OF CHILD SOLDIERS THROUGH POST-CONFLICT METHODS OF JUSTICE
}

JUSTIÇA DE TRANSIÇÃO: A REINTEGRAÇÃO DE CRIANÇAS-SOLDADO POR MEIO DE MÉTODOS DE JUSTIÇA PÓS-CONFLITO

JUSTICIA DE TRANSICIÓN: LA REINTEGRACIÓN DE NIÑOS SOLDADO POR MEDIO DE MÉTODOS DE JUSTICIA POSCONFLICTO

Ana Paula Barbosa-Fohrmanon ${ }^{2}$

$1 \quad$ Initial research for this paper was conducted at the United Nations Office of the Special Representative of the Secretary-General for Children and Armed Conflict (SRSGCAAC) during summer 2007.

2 Professor (Professora Adjunta) of Legal Theory at the Faculdade Nacional de Direito of the Universidade Federal do Rio de Janeiro (UFRJ). Full Staff Member of the Postgraduate Program in Law at UFRJ. Coordinator of the Research Group 'Theoretical Discourses on Human Rights' (NDTDH/FND/UFRJ). Post-PhD and PhD in Law at Ruprecht-Karls-Universität Heidelberg, Germany. 
Abstract: This paper, which examines the issue of child soldiers, is based, among other things, on the research and study strategy of the United Nations Office of the Special Representative of the Secretary-General for Children and Armed Conflict, and on the priorities of the Machel Study. Here, national and international law will be applied to countries where children are recruited by armed groups. Domestic jurisdiction alternative or traditional methods of justice and formal legal methods are addressed. Specifically, this paper focuses on three main subjects: 1) the possibility of prosecution and judgment of adolescents who have participated in armed conflicts; 2) prosecution and judgment of war lords and; 3) civil reparation proportional to the damage caused by an armed conflict. These three subjects are construed according to (traditional or alternative and formal) national and international law. Finally, some recommendations are made in order to improve the system of reintegration of child soldiers in post-conflict countries.

Keywords: Armed Conflict. Child Soldiers. Transitional Justice. Formal and Traditional Methods. Integration.

Resumo: Este artigo, que examina a problemática das criançassoldado, baseia-se, entre outros, na estratégia de pesquisa e estudo do Escritório das Nações Unidas da Representante Especial do Secretário-Geral para Crianças e Conflito Armado e nas prioridades do Estudo Machel. Aqui, o direito nacional e o direito internacional serão aplicados em países em que as crianças são recrutadas por grupos armados. Com relação à jurisdição doméstica, serão abordados métodos de justiça tradicionais e alternativos, assim como métodos jurídicos formais. Especificamente, este artigo vai enfocar três assuntos principais: 1) possibilidade de acusação e condenação de adolescentes que participaram de conflitos armados, 2) acusação e condenação dos denominados "senhores da guerra" e 3) reparação civil proporcional ao dano causado pelo conflito armado. Essas três questões vão ser desenvolvidas de acordo com o direito nacional (tradicional ou alternativo e formal) e o direito internacional. Por fim, serão feitas algumas recomendações a fim de aperfeiçoar o sistema de reintegração de crianças-soldado em países pós-conflito. 
Palavras-Chave: Conflito Armado. Crianças-Soldado. Justiça de Transição. Métodos Formais e Tradicionais. Integração.

Resumen: Este artículo, que examina la problemática de los niños soldado se basa, entre otros, en la estrategia de investigación y estudio de la Oficina de las Naciones Unidas del Representante Especial del Secretario General para la cuestión de los Niños y los Conflictos Armados y en las prioridades del Estudio Machel. Aquí el derecho nacional y el derecho internacional serán aplicados en países en los que los niños son reclutados por grupos armados. En relación a la jurisdicción doméstica, se abordarán métodos de justicia tradicionales y alternativos, así como métodos jurídicos formales. Específicamente, este artículo va a enfocar tres asuntos principales: 1) posibilidad de acusación y condenación de adolescentes que participaron en conflictos armados, 2) acusación y condenación de los denominados "señores de la guerra", y 3) reparación civil proporcional al daño causado por el conflicto armado. Esas tres cuestiones van a ser desarrolladas de acuerdo con el derecho nacional (tradicional o alternativo y formal) y el derecho internacional. Por último, se harán algunas recomendaciones a fin de perfeccionar el sistema de reintegración de niños soldado en países posconflicto.

Palabras Clave: Conflicto Armado. Niños Soldado. Justicia de Transición. Métodos Formales y Tradicionales. Integración.

INTRODUCTION

The expression 'transitional justice' has a wide range of approaches. A simple definition should be avoided, as 'transitional justice' can _ be analyzed from sociological, psychological, political, historical and legal points of view. This is confirmed by the following statement by the International Centre for Transitional Justice:

Transitional justice refers to the set of judicial and non-judicial measures that have been implemented by different countries in order to redress the legacies of massive human rights abuses. These measures include 
criminal prosecutions, truth commissions, reparation programs, and various kinds of institutional reforms. ${ }^{3}$

This paper analyzes transitional justice from a legal point of view, and addresses the issue of child soldiers, ${ }^{4}$ based inter alia on the research and study strategy of the United Nations Office of the Special Representative of the Secretary-General for Children and Armed Conflict (SRSGCAAC) ${ }^{5}$ and on the priorities of the Machel Study ${ }^{6}$ - children, education and reconciliation, children and reparations, children and criminal responsibilities, children and local justice mechanisms, children's hearings in truth and reconciliation commissions (TRCs), and the role of child protection agencies in transitional justice processes, adolescents and economic opportunities.

National and international law are applied to countries where children are recruited by armed groups. Concerning domestic jurisdiction, alternative or traditional methods of justice, as well as formal legal methods, are examined. Both methods are complementary and aim to promote accountability for perpetrations committed by leaders or armed groups, reconciling war-affected children and young people and reintegrating them into their own communities. This complementarity between national (alternative and formal justice) and international legal systems will be also addressed.

The same countries that serve as an example of analysis in a national legal system will be also analyzed in an international legal system. These countries are divided into three categories: 1 ) countries that have a transitional constitutional system (e.g. Southern Sudan); 2) countries that have a constitution and a developing national legal system (e.g. Sierra Leone and Democratic Republic of

3 INTERNATIONAL CENTER FOR TRANSITIONAL JUSTICE. What is Transitional Justice?, http:// www.ictj.org/about/transitional-justice (accessed on June 14, 2014).

4 According to Graça Machel child soldiers can be defined as follows: 'A child soldier is any child - boy or girl - under the age of 18 , who is compulsorily, forcibly or voluntarily recruited or used in hostilities by armed forces, paramilitaries, civil defense units or other armed groups.' See MACHEL, Graça. The Impact of War on Children. London: Hurst \& Company, 2001, p. 7.

5 SPECIAL REPRESENTATIVE OF THE SECRETARY-GENERAL FOR CHILDREN AND ARMED CONFLICT. Children and Armed Conflict. Strategic Framework 2006-2007 (unpublished manuscript, July 2007), p. 8.

6 UNITED NATIONS CHILDREN'S FUND. Machel Study. 10-Year Strategic Review. Mapping Note: Justice Processes and Reconciliation (unpublished manuscript, July 2007), p. 2-4. 
the Congo); 3) countries that have a developed constitutional and national legal system (e.g. Colombia).

Specifically, this paper focuses on three main topics: 1) the possibility of prosecution and judgment of adolescents who have participated in armed conflicts; 2) prosecution and judgment of war lords and; 3) civil reparation proportional to the damage caused by an armed conflict. These three subjects will be construed according to (traditional or alternative and formal) national and international law.

Last but not least, some recommendations will be made in order to improve the accountability for violations perpetrated against children in armed conflicts and to improve the reintegration of child combatants in a post-conflict society.

\section{ALTERNATIVE LAW: CULTURAL BACKGROUND AND TRADITIONAL METHODS OF JUSTICE}

This section analyzes the range of priorities of the Machel Study and the SRSGSCAAC. Initial observations are made on the cultural background and traditional methods of justice, such as healing, TRCs, and local courts that adopt traditional methods of justice.

Truth and reconciliation commissions and local courts that adopt traditional methods of justice apply a so-called 'restorative justice'. In a broad sense, this study is grounded on traditional values and practices that include mediation between the victim and offender, the family and other groups. In a narrow sense, it 'refers to any view of criminal justice that entails enhanced visibility of victims in terms of participation and reparation'.

HEALING

People affected by war adopt 'a wide range of cultural beliefs and practices to lay war traumas to rest and open the way to reconciliation and peace'. ${ }^{8}$ Healing 7 MUSILA, Godfrey M. The Participation of Victims in the International Criminal Court and the Question of Reparations. www.saifac.org.za/docs/2006/Musila\%20IWPR\%20Seminar\%20 Paper.pdf (accessed on April 19, 2013)) p, 4-5.

8 HONWANA, Alcinda. Child Soldiers in Africa. Philadelphia: University of Pennsylvania 
is therefore a cultural method, based on the tradition of community, religion, and communal beliefs, which seeks to release the child from the burden of the community's accusation of having participated in an armed conflict.

Moreover, it seeks to enable the child to be reintegrated into the life of his or her community. The reintegration of child soldiers in indigenous communities in Colombia serves as an illustration. Adults traditionally have a protective role of providing guardianship and wise counsel. In these communities, the adults order and the young obey without any feeling of submission, as it is understood that they must obey because in the future, they will perform the same role as their fathers. Obedience also gives them a sense of protection. Hence, when a child or young man or women is demobilized, they should be given a renewed sense that they are part of the community. ${ }^{9}$

\section{TRUTH AND RECONCILIATION COMMISSIONS (TRCS)}

Another kind of alternative method of justice is the $\mathrm{TRCs}_{1}{ }^{10}$ such as those of Burundi, Sierra Leone, South Africa and Liberia. In Sierra Leone, for instance, the TRC (2002-2004) served not only to expose perpetrators and identify victims, but also acted as a mirror through which all Sierra Leoneans were encouraged to examine their own roles in the conflict. This was also true for other nations that suffered violent conflict. In other words, truth commissions are temporary, non-judicial and non-punitive bodies that serve to document, to reconcile, to

Press, 2006, p. 105.

9 See the cultural meaning of membership in: WALZER, Michael. Spheres of Justice: A Defense of Pluralism and Equality. New York: Basic Books, 1983, p. 31. A completely opposite situation is how children enter armed groups. As Michael Wessells affirms: '... they frequently receive "training", a euphemism that often obscures a regime of brutality and psychological manipulation. Typically the training agenda serves not to develop military or survival skills, but to break children's will and achieve high levels of dominance and control. Not uncommonly, forced participation in atrocities provides the rite of initiation into an armed group.' See WESSELLS, Michael. Child Soldiers: From Violence to Protection. Cambridge: Harvard University Press, 2006), p.58.

10 AFAKO, Barney. To understand how the ICC functions, the crimes within its jurisdiction and the obligations assumed by Uganda. Workshop Report. The Implications of the International Criminal Court Investigations on Human Rights and the Peace Process in Uganda (5 October 2004), rapporteurs Eunice Apío and Issac Bakayana, www.iccnow.org/ documents/KampalaUHRCworkshop5Oct04.pdf (accessed on October 19, 2014, p. 7. 
promote accountability and healing and to reintegrate. ${ }^{11}$

The problem is whether children should be involved in the work of the TRCs, and whether this is in their best interest. ${ }^{12}$ The commissions should also distinguish between children below 18 and young people aged 18 years, and identify what kind of participation in the commissions is advisable for them. One of the reasons why this situation should be handled with care is that children and young people are in fact victims and witnesses to the perpetrations of war, and if the TRCs are not able to guarantee them protection, they could be subject to persecution by the armed group to which they belonged, or an opposing group.

\section{LOCAL COURTS THAT ADOPT TRADITIONAL METHODS OF JUSTICE. THE 'GACACA' COURTS}

In Rwanda, localized, semi-traditional 'gacaca' courts began their activities in 2002 and by 2005, the program was fully implemented throughout the country. The jurisdiction of the 'gacaca' courts can be categorized as cell, sector and appeal courts. The rules of procedure are strictly organized, and the courts have competences similar to ordinary courts. The sanctions related to genocide and passed by the 'gacaca' courts can vary from the death penalty to civil reparation (where property offenses are involved). ${ }^{13}$

The 'gacaca' courts could prosecute and judge adolescents who were aged between 14 and 18 at the time of genocide, whereas children aged under 14 at the time were not prosecuted at all. However, 14 to 18 year old adolescents could have their sanctions mitigated. Confession, a guilty plea, repentance and apology, or a combination of these factors, could be used as mitigating factors. ${ }^{14}$

11 UNICEF INNOCENTI RESEARCH CENTRE; THE INTERNATIONAL CENTER FOR TRANSITIONAL JUSTICE. Children and Truth Commissions. Florence: UNICEF, 2010, p. 9.

12 UNICEF INNOCENTI RESEARCH CENTRE; THE INTERNATIONAL CENTER FOR TRANSITIONAL JUSTICE. Children and Truth Commissions. Florence: UNICEF, 2010, p. 3.

13 OOMEN, Barbara. Rwanda's Gacaca: Objectives, Merits and Their Relation to Supranational Criminal Law. http://www.ucr.nl/about-ucr/Faculty-and-Staff/Social-Science/Documents/Barbara\%200omen/001_Oomen\%20Rwanda.pdf (accessed on September 25, 2014), p. 10.

14 OOMEN, Barbara. Rwanda's Gacaca: Objectives, Merits and Their Relation to Supranational Criminal Law. http://www.ucr.nl/about-ucr/Faculty-and-Staff/Social-Science/Documents/Barbara\%200omen/001_Oomen\%20Rwanda.pdf (accessed on September 25, 2014), p. 11. 


\section{FORMAL LAW: EXAMINING THE NATIONAL LEGAL SYSTEM}

\section{THE MEANING AND SCOPE OF TRANSITIONAL CONSTITUTIONS}

Following a military conflict caused by secessions and civil war, and that consequently dismantled a former state, it is expected that a new state will be born. This transitional period can be analyzed from a historical and cultural point of view, as well as sociologically, politically and legally. Legally, it involves the replacement of a former legal order of Public Law with a set of norms that are an outcome of the establishment and exercise of an original constitutional power, which will undertake the task of formulating the constitutional principles and the rules of new political and legal institutions.

A transitional constitution (TC) should be distinguished from a constitution itself. Those countries that were until recently under a TC, such as the Democratic Republic of the Congo (Constitution of April 1, 2003), ${ }^{15}$ and those still under a TC, such as Southern Sudan (The Interim Constitution of Southern Sudan, 2005, replaced by the Transitional Constitution of the Republic of South Sudan, 2011), ${ }^{16}$ are 'devised to provide legal frameworks for governing countries during periods of transition from crisis to stability'. ${ }^{17}$

15 Since May 2005, the Democratic Republic of the Congo (Kinshasa) has a new Constitution that is in force since February 8, 2006. See www.presidentrdc.cd/constitution.html (accessed on April 28, 2012). However, this does not mean that it found political and legal stability. On the contrary, the benefits that the new Constitution could have brought are now as risk, as the International Crisis Group warns: 'While the transition helped unify the divided country and improved security in much of it, governing institutions remain weak, abusive or non-existent, and the national army is still the country's worst human rights abuser, while another crisis is looming in the East.', www.crisisgroup.org (accessed on April 28, 2012).

16 An Interim Constitution of Southern Sudan was also drafted in 2005. See MAX-PLANCK INSTITUTE FOR COMPARATIVE AND INTERNATIONAL LAW. Interim Constitution of Southern Sudan. http://www.mpil.de/shared/data/pdf/interim_constitution_of_southern_sudan_2005. pdf (accessed on May 18, 2012).

17 ZIEGLER, Kai Peter. Democratic Republic of the Congo: The Transitional Constitution of April 1, 2003. International Journal of Constitutional Law vol. 3 number 4, p. 662-673, October 2005, p. 662. 
A TC is also a political instrument that enables a country to achieve sufficient internal stabilization to formulate a definitive constitution. As such, it can be regarded as a political agreement.

Therefore, measuring transitional constitutions by classical constitutional standards is inappropriate, because they differ fundamentally in their intentions, their period of applicability, and the conditions in which they are meant to prevail and under which they must operate. ${ }^{18}$

For instance, the TC of Democratic Republic of the Congo provided general provisions about the exercise of power and the form of State, transitional institutions, and the distribution of power, e.g. the security forces, and other transitional provisions. In Southern Sudan, a TC drafted in 2005 contained 226 articles, and was divided into seventeen parts. For example, part I dealt with the state, constitution and guiding principles; part II covered the bill of rights. Within the bill of rights, there were provisions on human dignity, the right to life and integrity (Art. 28), and a specific provision on the rights of women and children (Art. 32). Parts III, IV and V contained norms about the organization and functions of the Legislative, Executive and Judiciary powers. Part XVI provided specific norms on Southern Sudan's Right to Self-Determination. ${ }^{19}$ As a TC, the Interim Constitution of Southern Sudan had a more detailed profile than the TC of Democratic Republic of the Congo, which was influenced by the French Constitution of 1958.

Southern Sudan has had a new TC since 2011. Its Art. 11 establishes the protection of life and human dignity, and an explicit provision on the rights of children was maintained. Inter alia, art. 17 (1) determines that every child has the right ' $(d)$ not to be subjected to exploitative practices or abuse, nor to be required to serve in the army nor permitted to perform work which may be hazardous or harmful to his or her education, health or well-being', and (h) to be protected

18 ZIEGLER, Kai Peter. Democratic Republic of the Congo: The Transitional Constitution of April 1, 2003. International Journal of Constitutional Law vol. 3 number 4, p. 662-673, October 2005, p. 662.

19 MAX-PLANCK INSTITUTE FOR COMPARATIVE AND INTERNATIONAL LAW. Global Knowledge Transfer. http://www.mpil.de/ww/en/pub/research/details/know_transfer.cfm (accessed on May 23, 2013). 
against abduction and trafficking'. Part III deals with fundamental objectives and guiding principles, citizenship and nationality, and the decentralized system of government. Part IV deals with the national government, Part V, with the national legislature, Part VI, with the national executive, and Part. VII, with the judiciary. Part IX establishes, among other things, a human rights commission, and a demobilization, disarmament and re-integration commission. This TC will remain in force until the adoption of a permanent constitution (art. 199 [2]).

A TC can, therefore, be regarded as a political and legal compromise or a path towards the formulation of a definitive Constitution that should correspond to the wishes, hopes and interests of a nation. ${ }^{20}$

\section{CONSTITUTION AS A NATIONAL SYMBOL OF STABILITY}

As a national agreement that gives birth to a new political organization i.e. a new state, a constitution can serve as a national symbol of stabilization. It is not a piece of paper ${ }^{21}$ without effectiveness and influence over a people's consciousness. On the contrary, it can reinforce national unity because the people identify with it.

As a symbol, the constitution can produce safe social relations, if the people allow themselves to be led by a so-called 'constitutional feeling', i.e. if the people begin to trust in its meaning, in the social effectiveness of its principles and rules, and in the functioning of its institutions, and its Legislative, Executive and Judiciary powers. Only then will the state have a chance of surviving in the future.

20 The same cultural background (religion, race, ethnic, language, etc.) defines the content of the concept of a nation. However, nowadays the classical meaning of nation should be readjusted in order to admit that different nationalities can live in one nation. In this study this can be observed for example in the case of the Southern Sudan. The Interim National Constitution takes into consideration the fact that the 'nation' of the Sudan is a reunion of different nationalities. For instance, its Preamble provides that 'We the people of the Sudan ... Mindful of religion, racial, ethnic and cultural diversity in the Sudan ... Do hereby adopt this Constitution as the supreme law by which the Republic of the Sudan shall be governed during the Interim Period; and we undertake to respect and protect it.' See MAX-PLANCK INSTITUTE FOR COMPARATIVE AND INTERNATIONAL LAW. Global Knowledge Transfer. http://www.mpil. de/ww/en/pub/research/details/know_transfer.cfm (accessed on May 23, 2013).

21 The German jurist and socialist political activist Ferdinand Lassalle asked in the beginning of a lecture in 1862: 'What is a Constitution?' He answered by stating that it is a mere piece of paper without effect. See LASSALLE, Ferdinand. On the Essence of Constitutions (speech delivered in Berlin, Germany, 16 April 1862), http://www.marxists.org/history/etol/newspape/fi/vol03/no01/lassalle.htm (accessed on 24 May 2014). 
Some principles and rules are common to many constitutions. The legal order, which is founded in the countries under transitional constitutions (e.g. Southern Sudan), or which has already been established within a developed constitutional and legal system (e.g. Colombia), should be in accordance with the constitutional order. This is true of all laws and codes, particularly those related to children and armed conflict. Therefore, agreement between the legal and constitutional orders can result in safety and stability for the entire system, and reinforce the legal and social efficacy of the rules, in terms of accountability and reintegration of child soldiers who are, for instance, protected by penal, civil and child codes.

The rules of law, sovereignty and democracy can be enrolled as constitutional principles. Human dignity can be seen as a principle, or as a rule of the bill of rights. Sustainable development, peace and disarmament can be regarded as constitutional purposes. The bill of rights can include right of freedom and equity, the right to life and physical integrity, and the right to a due process of law. These principles and rules can be found, for example, in the constitutions of Colombia (2001), the Democratic Republic of the Congo (2005) and Sierra Leone (1991).

According to the Constitution of the Democratic Republic of the Congo (2005), the country is governed by the rule of law, sovereignty and democracy (Art. 1), among other things. Human dignity (Art. 11), equity (Art. 12), and life and physical integrity (Art. 16), for example, belong to the catalogue of human rights. The Constitution of Colombia (2001) contains similar provisions, such as Art. 1 (fundamental principles - rule of law, democracy and human dignity) and Art. 2 (objectives of the state - peaceful coexistence). It also has a bill of rights. Among other relevant provisions, it includes Art. 11 (right of life), Art. 13 (right to freedom and equity) and Art. 29 (right to due process of law). Likewise, the Constitution of Sierra Leone (1991) contains fundamental principles - Art. 5 (1) - freedom, democracy and justice; Art. 5 (2) (b) - security, peace and welfare; Art. 6 (4) - rule of law, liberty of the individual, and a catalogue of human rights; for instance, Art. 16 contains the protection of the right to life; Art. 19 - protection from slavery and forced labor and Art. 20 - protection from inhumane treatment. 


\section{NATIONAL LEGISLATION ON TRANSITIONAL JUSTICE IN ITS WIDE AND NARROW SENSES}

Constitutional principles and rules produce effect in the national legislations, particularly in the field of transitional justice and children in armed conflicts. In this regard, it is necessary to distinguish between two types of legislation, namely, a legislation that deals with transitional justice in general, and a legislation that deals with transitional justice and the issue of children in armed conflict.

In a wide or general sense, transitional justice deals with a new legislation, because countries are coming out of an internal armed conflict, or they were under a dictatorship and are now in a transitional process to democracy. A new legislation (penal, civil and administrative law) based on a new constitutional model is imperative to reestablish state order.

In a narrow or specific sense, transitional justice deals with the issue of children that were demobilized and should be reintegrated into their society and communities. This new legislation can be divided into the need to formulate a child code and establish and implement a system of penal responsibility, which means differentiating between children under 18 years of age and young people aged 18 years, rehabilitating children and adolescents, and bringing accountability and prosecution of war lords. Civil reparation that is appropriate to children is another specific object of civil law.

\section{IS IT POSSIBLE TO PROSECUTE AND JUDGE DEMOBILIZED}

ADOLESCENTS?

Colombia is an example of a country under conflict that has a developed legal system, specifically in regard to child legislation. The new child code (Código de Infancia y Adolescencia) has been in force in Colombia since 2006. Some principles and rules of the 1991 Colombian Constitution are reflected in this child code. For example, the Colombian constitution refers to the right to life, as mentioned above, and this rule is also prescribed in the Colombian new child code (Art. 
17). Other rules that can be considered constitutional repercussions are Art. 18 (child's physical integrity), Art. 25 (child's right to due process of law), Art. 26 (right to health care) and Art. 27 (right to education).

However, the new child code does not distinguish between children and adolescents aged 18 years and young people aged 18 years. Adolescents between the ages of 14 and 18 can be condemned to imprisonment for eight years when they have committed acts of murder, extortion and kidnapping. Adolescents aged 16 to 18 years will be also penalized when they have committed a crime, the penalty for which, according to the Colombian penal code, is more than six years. ${ }^{22}$ In this regard, the Colombian new child code considers children recruited under coercion for armed groups not as victims of antipersonnel mines, abuse and sexual exploitation, trafficking, kidnappings, servitude, torture, forced labor and whippings, ${ }^{23}$ but as perpetrators. This is, effectively, a legislative regression, as it violates not only the constitutional principle of human dignity and the aforementioned rules on human rights, but also the humanitarian principle of higher interest of the child, who requires the protection of the state in such cases. ${ }^{24}$

Children and adolescents under the age of 18 should be considered witnesses of forced recruitment. A special program of juvenile rehabilitation without deprivation of personal liberty ${ }^{25}$ would be more appropriate, as it would promote

22 MITTRANY, Carola. Nova Lei da Infância da Colômbia Ignora Tratados Internacionais, translation: Aline Gatto Boueri, http://www.comunidadesegura.org.br/fr/node/33281?q=en/ node/31285 (accessed on May 25 2013).

23 LA AGENCIA DE LA ONU PARA LOS REFUGIADOS (ACNUR). Intervención del ACNUR en la Audiencia de la Corte Constitucional sobre el Enfoque Diferencial de Edad desde la Perspectiva de los Niños(as) y Adolescentes Desplazados(as) (unpublished manuscript, June 2007), p. 1.

24 LA AGENCIA DE LA ONU PARA LOS REFUGIADOS (ACNUR). Intervención del ACNUR en la Audiencia de la Corte Constitucional sobre el Enfoque Diferencial de Edad desde la Perspectiva de los Niños(as) y Adolescentes Desplazados(as) (unpublished manuscript, June 2007), p. 5. The Convention on the Rights of the Child does not establish a minimum age for criminal responsibility. However, the Committee on the Rights of the Child emphasizes that the age should not be set too low. See NO PEACE WITHOUT JUSTICE; UNICEF INNOCENTI RESEARCH CENTRE. International Criminal Justice and Children. http://www.unicef. org/emerg/files/ICJC.pdf (accessed on May 25, 2012), p. 22.

25 Rehabilitation seeks to enable people to live in society again, and interact with other individuals without threatening the security of their lives and personal integrity. In other words, social reintegration is the purpose of a rehabilitation program. However, some rehabilitation programs can make people more violent than when they first entered the program. This is true, for example, in countries like Brazil and Colombia, which have a developed constitutional, penal legislation and child code that are not socially effective. 
children's respect for penal law. This is important because children and adolescents who have participated in armed conflicts have been trained to obey commands and carry out orders, without thinking about why they are committing crimes against the lives, physical integrity, and property of others. In Sierra Leone, for instance, 'they were abducted and made to terrorize the civilian population, including amputating the limbs of civilians'. ${ }^{26}$

The question is, what happens when the demobilized person is 18 years old. Is the same special program of rehabilitation appropriate in these cases? Or should they be prosecuted and judged in the same way as an adult who had had committed a crime against human rights principles and rules? Should this situation be analyzed strictly from a perspective of formal and dogmatic law? Simply applying the rules of penal law to all cases cannot be recommended. Constitutional law could play an important role as a basis of legitimation or justification for the whole legal system, including the application of penal law. A balance should be found between constitutional principles, such as liberty, equality and human dignity, which underpin the whole legal system.

\section{PROSECUTION AND JUDGMENT OF WAR LORDS}

In the context of retributive justice, national courts undertake the task of prosecuting and judging war lords. ${ }^{27}$ However, when the Judiciary is not able to accomplish with it, perpetrators of human rights, particularly children, should be transferred to international courts or tribunals in order to be judged. In TC countries (e.g. Southern Sudan) and in countries with a constitution but with a developing legal system (e.g. Democratic Republic of the Congo and Sierra Leone) persecution, accountability and judgment of war lords do not exist legally and therefore cannot produce social and legal efficacy. In these cases, the role of the

26 NO PEACE WITHOUT JUSTICE; UNICEF INNOCENTI RESEARCH CENTRE. International Criminal Justice and Children. http://www.unicef.org/emerg/files/ICJC.pdf (accessed 25 May 2012), p. 33.

27 Retributive justice involves imposing a sanction or punishment on those guilty for committing a crime. See MUSILA, Godfrey M. The Participation of Victims in the International Criminal Court and the Question of Reparations. www.saifac.org.za/docs/2006/Musila\%20 IWPR\%20Seminar\%20Paper.pdf (accessed on April 19, 2013), p. 4. 
international courts and tribunals is imperative, to prevent impunity. Colombia is a special case because it has a developed constitutional and legal system. Despite this, the whole system was, for many years, subject to violence, corruption and consequently, judicial inefficacity. ${ }^{28}$ Under the 2001 Constitution, this panorama is expected to change.

\section{CIVIL REPARATION}

State responsibility includes investigation, persecution and material compensation for human rights violations committed within its territory. When an action or omission of the state involves a serious violation of human rights, the individual has the right to prosecute the state in order to recover compensation for material and psychological damages. That is how state civil responsibility or civil reparation can be defined, in general terms.

The question is whether civil reparation is appropriate for children, and if it is, what kind of civil reparation they should obtain from the state to compensate for the damages caused by their forced participation in armed groups. This compensation could be converted in social reintegration; for example, a proportional amount of money that could allow the child to go back to school, to have access to medical and psychological assistance, and to fulfill his or her basic needs for sustenance. These three conditions are deemed the social minimum for existence worthy of human dignity.

However, TC countries (e.g. Southern Sudan) and countries with a developing legal system (e.g. the Democratic Republic of the Congo and Sierra Leone), and even countries with a developed legal system (e.g. Colombia), cannot afford to give compensation for physical and psychological damages that were caused by internal turmoil and that could reintegrate the child or adolescent into the society. In Sierra Leone, for instance, the TRC recommended, in 2004, that the government implement effective measures to pay reparation for war victims, such as amputees and victims of sexual violence. The TRC called for provisions such

28 PECAUT, Daniel. 'Presente, pasado y futuro de la violencia en Colombia' Desarrollo Económico. Revista de Ciencias Sociales vol. 144, number 36, p. 1-43, January-March 1997. 
as free medical care and monthly allowances. In 2005, however, the government merely made proposals to implement TRC recommendations ('White Paper on the Truth and Reconciliation Project'). The White Paper simply stated that the government would do its best to pay the reparations, given the amount of resources available. ${ }^{29}$

\section{FORMAL LAW: EXAMINING THE INTERNATIONAL LEGAL SYSTEM}

With respect to international legal order, it is important to systematize declarations and statutes (General Declaration on Human Rights, Rome Statute of the International Criminal Court [hereinafter 'Rome Statute'] ${ }^{30}$ ), as well as covenants (Covenant on Civil and Political Rights, Covenant on Economic, Social and Cultural Rights), conventions (Convention against Torture and other Cruel Penalties, Convention on the Rights of Child $^{31}$ ), protocols (Optional Protocol to the Convention on the Rights of the Child on the Involvement of Children in Armed Conflict ${ }^{32}$ ), reports (The Impact of Armed Conflict on Children - The Graça Machel Report ${ }^{33}$, Reports of the Special Representative of the Secretary-General for Children and Armed Conflict) and UNSC resolutions on Children and Armed Conflict from 1995 to 2005.

For instance, the rationale of UNSC Resolution 1612 of July 26, 2005 is to provide implementation and effectiveness to the aforementioned international norms and standards for the protection of children affected by armed conflict, through monitoring and reporting mechanisms. ${ }^{34}$ In accordance with the purpose 29 See THE HUMANITARIAN NEWS AND ANALYSIS SERVICE OF THE UN OFFICE FOR THE COORDINATION OF HUMANITARIAN AFFAIRS (IRIN) 'SIERRA LEONE: Civil society criticizes "vague" government plan for post-war reform', IRIN, 13 July 2005, http://www.un-ngls. org/orf/cso/cso9/sierra-leone.htm. (accessed on November 5, 2013).

30 Rome Statute of the International Criminal Court, adopted 17 July 1998, came into force July 1, 2002, 2187 UNTS 90 (Rome Statute).

31 Convention on the Rights of the Child, adopted 20 November 1989, came into force September 2, 1990, 1577 UNTS 3.

32 Optional Protocol to the Convention on the Rights of the Child on the Involvement of Children in Armed Conflict, adopted 25 May 2000, came into force February 12, 2002, 2173 UNTS 222.

33 UNITED NATIONS GENERAL ASSEMBLY. Promotion and Protection of the Rights of Children. Impact of Armed Conflict on Children (26 August 1996) UN Doc A/51/306.

34 UNITED NATIONS SECURITY COUNCIL. Res 1612 on Children and Armed Conflict (S/ RES/1612 [2005]). 
of this resolution, the SRSG/CAAC published a report on September 7, 2005, which supports advocacy, the application of international norms and standards for the protection of the rights, and rehabilitation of children affected by war. In other words, its priorities and recommendations reiterate the content of the UNSC Resolution. ${ }^{35}$

Based on the UNSC Resolution and SRSG/CAAC Report, legal effectiveness means concrete measures to ensure prosecution and judgment of those who have participated in armed conflict, and civil reparation from the state commensurate to the physical and psychological damage caused.

\section{IS IT POSSIBLE TO PROSECUTE AND JUDGE DEMOBILIZED} ADOLESCENTS?

It is difficult to determine the age at which adolescents should be prosecuted and judged for violations against human rights perpetrated during their recruitment and participation in armed groups. Art. 40 of the Convention on the Rights of the Child supports the idea that children and adolescents should be primarily regarded as witnesses of armed conflicts and 'presumed innocent until proven guilty according to law'. ${ }^{36}$ Furthermore, the convention does not establish a minimum age at which an adolescent is deemed capable of infringing penal law. It requires the state's reasonableness to define it. This sense of reasonableness can be deduced from the content of Art. 40, which states that: 'The establishment of a minimum age below which children shall be presumed not to have the capacity to infringe the penal law. ${ }^{37}$ In other words, the minimum age should not be too low.

For instance, the Special Court for Sierra Leone has jurisdiction to prosecute persons aged 15 years. Art. 7 (1) of its statute states:

35 SPECIAL REPRESENTATIVE OF THE SECRETARY-GENERAL FOR CHILDREN AND ARMED CONFLICT. Report of the Special Representative of the Secretary-General for Children and Armed Conflict (S/2005/72 [2005]) (unpublished document, July 2007), p. 16-17.

36 Convention on the Rights of the Child, adopted 20 November 1989, came into force on September 2, 1990, 1577 UNTS 3.

37 Convention on the Rights of the Child, adopted 20 November 1989, came into force on September 2, 1990, 1577 UNTS 3. 
The Special Court shall have no jurisdiction over any person who was under the age of 15 at the time of the alleged commission of the crime. Should any person who was between 15 and 18 years of age at the time of the alleged commission of the crime come before the Court, he or she shall be treated with dignity and a sense of worth, taking into account his or her young age and the desirability of promoting his or her rehabilitation, reintegration into and assumption of a constructive role in society, and in accordance with international human rights standards, in particular the rights of the child..$^{38}$

But the judgment should be made on a case by case basis, and in accordance with the interpretation and application of the principle of reasonableness and the principle of the higher interests of the child. ${ }^{39}$ The court should find a balance between the young person's intention, the act committed, and the purpose of the act, and should take into consideration the fact that the adolescent was coercively recruited by armed group(s), without having any other choice.

\section{PROSECUTION AND JUDGMENT OF WAR LORDS}

Crimes against human rights perpetrated by war lords during a civil war should be prosecuted and judged by international courts or tribunals if the national courts are unable to act with independency and the judges with impartiality, or if the due process of law cannot be guaranteed. International criminal courts perform then a subsidiary and complementary role in relation to the jurisdiction of the national courts. ${ }^{40}$ For instance, in March 2006 the ICC announced the arrest of Thomas Lubanga. In March 2012 he was found guilty of recruiting children and forcing them to kill and mutilate the enemies. A sentence of 14 years imprisonment was delivered on 10 July $2012 .{ }^{41}$ Charles Taylor is also an important case that was under prosecution and judgment by the Special Court for Sierra Leone. Charles

38 Agreement on the Establishment of a Special Court for Sierra Leone, adopted on January 16, 2002, came into force on April 12, 2002, 2178 UNTS 137.

39 Art. 3 (3) of the Convention on the Rights of the Child provides: 'In all actions concerning children, whether undertaken by public or private social welfare institutions, courts of law, administrative authorities or legislative bodies, the best interests of the child shall be a primary consideration.'

40 OOMEN, Barbara. Rwanda's Gacaca: Objectives, Merits and Their Relation to Supranational Criminal Law. http://www.ucr.nl/about-ucr/Faculty-and-Staff/Social-Science/Documents/ Barbara\%200omen/001_Oomen\%20Rwanda.pdf (accessed on September 25, 2014), p. 2.

41 Prosecutor v. Thomas Lubanga Dyilo - Case ICC - 01/04-01/06. 
Taylor, the former President of Liberia, was indicted in March 2003 and sentenced to a single term of imprisonment of 50 years in May 2012. ${ }^{42}$ He faced an 11count indictment for crimes against humanity, violations of Article 3 common to the four Geneva Conventions and Additional Protocol $\mathrm{II}^{43}$, and other serious violations of international humanitarian law, such as enlisting and conscripting children under the age of 15 into armed forces or groups, or using them to participate actively in hostilities.

\section{CIVIL REPARATION}

Reparation is one of the pillars of the ICC regime. Art. 75 of the Rome Statute states that reparation to the victims can take the form of restitution, compensation or rehabilitation. Reparation can be provided either upon request to the state or on the ICC 'own motion in exceptional circumstances'. ${ }^{44}$ In these cases, the ICC establishes the 'scope and extent of any damage'. Furthermore, 'the award for reparations (will) be made through the Trust Fund (Art. 79)'.45

However, as analyzed above, the ICC Statute is complementary to traditional and formal legal systems in cases where the state is unable or unwilling to investigate, prosecute and judge perpetrators.

\section{RECOMMENDATIONS FOR CONSOLIDATING A TRANSITIONAL JUSTICE SYSTEM: THE REINTEGRATION OF CHILD SOLDIERS}

Countries that have experienced social, political and economical destruction and disruption and are going through a transitional period towards a new legal

42 BOWCOTT, Owen and agencies. Charles Taylor sentenced to 50 years in prison for war crimes. The Guardian, May 30, 2012, http://www.theguardian.com/world/2012/may/30/ charles-taylor-sentenced-50-years-war-crimes (accessed on August 10, 2013).

43 Protocol Additional to the Geneva Conventions of 12 August 1949, and relating to the Protection of Victims of Non-International Armed Conflicts (Protocol II), adopted 8 June 1977, entered into force 7 December 1978, 1125 UNTS 609.

44 Rome Statute of the International Criminal Court, adopted 17 July 1998, entered into force 1 July 2002, 2187 UNTS 90 (Rome Statute).

45 Rome Statute of the International Criminal Court, adopted 17 July 1998, entered into force 1 July 2002, 2187 UNTS 90 (Rome Statute). 
and political order (e.g. the Democratic Republic of the Congo and Southern Sudan) or countries that have a constitutional system (constitution and other legal instruments - penal and civil code, for instance), but are suffering the social and political upheaval caused by armed conflicts (e.g. Colombia), should develop trust in its national legal order.

\section{LEGAL TRAINING}

In order to develop this trust, particularly in the cases of Southern Sudan and the Democratic Republic of the Congo, legal training should be provided for the Sudanese and Congolese legal experts, in collaboration with research centers engaged in examining the issue of the legal reconstruction of societies in the aftermath of armed conflict. Examples are the Max-Planck Institute for Comparative Public Law and International Law, and the International Center for Transitional Justice. Legal training could also be provided by the United Nations Institute for Training and Research (UNITAR), UNICEF - Innocenti Research Centre, and the United Nations Legal Office.

The same training could be developed by the national and local courts. According to a statement by the ICC Office of the Prosecutor, there should be a 'positive approach to complementarity', ${ }^{46}$ and the ICC should encourage national proceedings, which could embrace 'supporting local investigations, the provision of forensic expertise and the arrangement of drafting of enabling legislation for the implementation of the statute' ${ }^{47}$

46 INTERNATIONAL CRIMINAL COURT. Statement of the Prosecutor Luis Moreno Ocampo to Diplomatic Corps, The Hague, Netherlands. (February 12, 2004) http://www.icc-cpi.int/NR/ rdonlyres/0F999F00-A609-4516-A91A-80467BC432D3/143670/LOM_20040212_En.pdf (accessed 10 February 2013). See also OOMEN, Barbara. Rwanda's Gacaca: Objectives, Merits and Their Relation to Supranational Criminal Law. http://www.ucr.nl/about-ucr/Faculty-and-Staff/Social-Science/Documents/Barbara\%200omen/001_Oomen\%20Rwanda. pdf (accessed on September 25, 2014), p. 2.

47 INTERNATIONAL CRIMINAL COURT NETWORK. Final Narrative Report: The International Criminal Court \& the Arab World. Amman, Jordan (February 14-16, 2005) http://www.icln. net/documents/Narrative\%20Report.pdf (accessed on June 10, 2012). See also OOMEN, Barbara. Rwanda's Gacaca: Objectives, Merits and Their Relation to Supranational Criminal Law. http://www.ucr.nl/about-ucr/Faculty-and-Staff/Social-Science/Documents/Barbara\%200omen/001_Oomen\%20Rwanda.pdf (accessed on September 25, 2014), p. 2. 


\section{CAPACITY BUILDING}

The human dignity of the child should be respected and guaranteed. According to Art. 40 of the Convention on the Rights of the Child, when the child's dignity is ensured, this leads them not only respect human rights and the fundamental freedoms of others, but also this enables them to be reintegrated and to assume a constructive role in society. A range of measures, such as medical and psychological assistance, guidance, and supervision orders, counseling, probation, foster care, basic education, vocational training programs, distance learning programs, technical education and other alternatives to institutional care should be available to ensure that children are dealt with in a manner appropriate to their wellbeing, and proportionate both to their circumstances and the offence.

\section{MONITORING THE JUDICIAL SYSTEM}

The UN, together with the legal offices of the $\mathrm{NGOs}^{48}$, could monitor how the judiciary system is being rebuilt in TC countries or in countries with an emerging legal system, and the benefits to be derived from alternative and traditional methods of promoting justice. For instance, crimes committed during decades of internal conflict are judged only according to the penal code. However, the penal code could also have expressed rules which determine that war crimes can also be prosecuted within the traditional system of justice.

\section{NO AMNESTY FOR DEMOBILIZED ARMED GROUPS}

When armed groups are demobilized, they may not receive amnesty for the atrocities they perpetrated during the conflict. This kind of judicial benefit tends

48 The participation of NGOs can improve the effectiveness of this kind of initiative through coordination and cooperation, which means an exchange of information and pooling of efforts. NGOs statements also attract media attention, which adds concreteness to their activities. As Peter R. Baehr, Professor and Director of Netherlands Institute for Human Rights of the University of Utrecht, states: 'Publicity is needed in order to seek public pressure to affect government's attitudes and behavior.' See BAEHR, Peter R. Mobilization of the Conscience of Mankind: Conditions of Effectiveness of Human Rights and NGOs. UN University Lectures 14, 15, http://archive.unu. edu/unupress/lecture14-15.html (accessed on September 15, 2012). 
to reinforce impunity and weaken the national and international judicial system on human and humanitarian rights.

Not granting amnesty to the leaders and members of armed groups, who committed crimes against children's rights, is based on Resolution $1314(2000)^{49}$ and $1379(2001)^{50}$. Resolution 1314 (2000) [2] emphasizes

the responsibility of all States to put an end to impunity and to prosecute those responsible for genocide, crimes against humanity and war crimes, and, in this regard, stresses the need to exclude these, where feasible, from amnesty provisions and relevant legislation.

Resolution 1379 (2001) [9 (a)] reinforces the content of paragraph 2 of the previous Resolution 1314 by urging Member States

to put an end to impunity, prosecute those responsible for genocide, crimes against humanity, war crimes, and other egregious crimes perpetrated against children and exclude, where feasible, these crimes from amnesty provisions and relevant legislation...

\section{ECONOMIC RESOURCES}

Economic resources are an important aspect for the reconstruction of waraffected countries and people, and can be regarded in both wide and narrow senses.

In a wide sense, the production of economic resources can aid the recovery of wars and prevent new ones. In order to foster sustainable production, public and private economic and social actors play an important role. Given that disputes for valuable natural resources are the motive of wars, state companies, in association with private companies, could produce not only to fulfill private and economical interests, but also to rebuild a post-conflict society.

In a narrow sense the production of resources is associated with the social responsibility of those companies, which involves, for instance, the employment of 
demobilized soldiers, providing support for technical education for demobilized adolescents, and maintaining ethical standards, such as non-exploitation of children in a labor force.

\section{JUDICIAL TIMING}

Formal methods of justice, such as investigation, prosecution and judgment by the national courts, should be in keeping with alternative or traditional methods of justice adopted by the TRCs and the national and local courts.

The recommendations of the TRCs could be incorporated by the national courts as a solid source of evidence to interpret and apply the formal law. In this regard, the work of the TRCs and the national tribunal or courts should work in harmony with each other. Their work should not overlap, as that would not only discredit the political and social value of the TRC's work, but would also create uncertainty for the judgments and decisions of the national and local courts.

Furthermore, the jurisdiction of national and local courts that adopts traditional methods of justice should not be overlapped by the prosecution and judgment of the international courts and tribunals. The notion of complementarity, enshrined by the Rome Statute, should be followed, which means the international courts have the initiative to investigate, prosecute and judge only when the national and local courts are unable to do so.

CONCLUSION

This article argues that complementarity between formal and alternative methods, including national and international law, and TRCs, can produce promising results. The concluded trials of warlords Charles Taylor and Thomas Lubanga illustrate the positive nature of this complementarity.

Child soldiers should be considered primarily as victims of internal conflicts and, accordingly, 'presumed innocent until proven guilty according to law'. States must also act with reasonableness in setting the age limit for the prosecution of adolescents. 
The 'gacaca' courts have set a limit of 14 years for the trial, but the sentence can be mitigated based on the degree of co-operation of the adolescent in the trial. The Special Court for Sierra Leone establishes an age limit of 15 years in its statute.

On the level of national law, the situation of the countries that are still under constitutional transition was analyzed, as well as the situation of those countries that have recently enacted a constitution. Confidence in the constitution and its institutions must still be built. This aspect is important, as the state could then be consolidated in the years ahead and not be subject to constant institutional breaks, which obstruct any stabilization of democratic structures.

The case of Colombia called our attention because it is a country that has a consolidated legal system, with a constitution, child and criminal code. According to the child code, a 14 year old boy or girl can be sentenced to eight years imprisonment. Colombia is a clear example of a country where the repressive penal system imposed on demobilized adolescents of 14 years of age could be revised and replaced. This could be done through a special program of rehabilitation for adolescents, without depriving them of personal liberty, or through a process of healing, according to the cultural method of reintegration of child soldiers that is already being applied by Colombian indigenous communities. Or, the repressive penal system could be at least mitigated by taking the trials of the 'gacaca' courts as a good example of reflection on its own judicial system.

Finally, this paper makes some recommendations that can improve the reintegration of child soldiers into their own communities. These recommendations are based on the priorities of the Machel Study: legal training, capacity building, and monitoring the judicial system, without amnesty for demobilized armed groups, economic resources, and judicial timing.

\section{SELECT BIBLIOGRAPHY}

AFAKO, Barney. To understand how the ICC functions, the crimes within its jurisdiction and the obligations assumed by Uganda. Workshop Report. The Implications of the International Criminal Court Investigations on Human Rights and the Peace Process in Uganda 
(October 5, 2004), rapporteurs Eunice Apío and Issac Bakayana, www.iccnow.org/documents/ KampalaUHRCworkshop5Oct04.pdf (accessed on October 19, 2014.

BAEHR, Peter R. Mobilization of the Conscience of Mankind: Conditions of Effectiveness of Human Rights and NGOs. UN University Lectures 14, 15, http://archive.unu.edu/unupress/ lecture14-15.html (accessed on September 15, 2012).

BOWCOTT, Owen and agencies. Charles Taylor sentenced to 50 years in prison for war crimes. The Guardian, May 30, 2012, http://www.theguardian.com/world/2012/may/30/charlestaylor-sentenced-50-years-war-crimes (accessed August 10, 2013).

HONWANA, Alcinda. Child Soldiers in Africa. Philadelphia: University of Pennsylvania Press, 2006.

INTERNATIONAL CENTER FOR TRANSITIONAL JUSTICE. What is Transitional Justice?, http:// www.ictj.org/about/transitional-justice (accessed on June 14, 2014).

INTERNATIONAL CRIMINAL COURT. Statement of the Prosecutor Luis Moreno Ocampo to Diplomatic Corps, The Hague, Netherlands. (12 February 2004) http://www.icc-cpi.int/NR/ rdonlyres/0F999F00-A609-4516-A91A-80467BC432D3/143670/LOM_20040212_En.pdf (accessed on February 10, 2013).

LA AGENCIA DE LA ONU PARA LOS REFUGIADOS (ACNUR). Intervención del ACNUR en la Audiencia de la Corte Constitucional sobre el Enfoque Diferencial de Edad desde la Perspectiva de los Niños(as) y Adolescentes Desplazados(as) (unpublished manuscript, June 2007).

LASSALLE, Ferdinand. On the Essence of Constitutions (speech delivered in Berlin, Germany, on April 16, 1862), http://www.marxists.org/history/etol/newspape/fi/vol03/no01/lassalle. htm (accessed on May 24, 2014).

MACHEL, Graça. The Impact of War on Children. London: Hurst \& Company, 2001.

MAX-PLANCK INSTITUTE FOR COMPARATIVE AND INTERNATIONAL LAW. Interim Constitution of Southern Sudan. http://www.mpil.de/shared/data/pdf/interim_constitution_of_southern_ sudan_2005.pdf (accessed on May 18, 2012).

MAX-PLANCK INSTTUUTE FOR COMPARATIVE AND INTERNATIONAL LAW. Global Knowledge Transfer. http://www.mpil.de/ww/en/pub/research/details/know_transfer.cfm (accessed on May 23, 2013).

MITTRANY, Carola. Nova Lei da Infância da Colômbia Ignora Tratados Internacionais, translation: Aline Gatto Boueri, http://www.comunidadesegura.org.br/fr/node/33281?q=en/node/31285 (accessed on May 25, 2013) 
MUSILA, Godfrey M. The Participation of Victims in the International Criminal Court and the Question of Reparations. www.saifac.org.za/docs/2006/Musila\%20IWPR\%20Seminar\%20 Paper.pdf (accessed on April 19, 2013).

NO PEACE WITHOUT JUSTICE; UNICEF INNOCENTI RESEARCH CENTRE. International Criminal Justice and Children. http://www.unicef.org/emerg/files/ICJC.pdf (accessed on May 23, 2012).

OOMEN, Barbara. Rwanda's Gacaca: Objectives, Merits and Their Relation to Supranational Criminal Law. http://www.ucr.nl/about-ucr/Faculty-and-Staff/Social-Science/Documents/ Barbara\%200omen/001_Oomen\%20Rwanda.pdf (accessed on September 25, 2014).

PECAUT, Daniel. 'Presente, pasado y futuro de la violencia en Colombia' Desarrollo Económico. Revista de Ciencias Sociales vol. 144, number 36, p. 1-43, January-March 1997.

SPECIAL REPRESENTATIVE OF THE SECRETARY-GENERAL FOR CHILDREN AND ARMED CONFLICT. Children and Armed Conflict. Strategic Framework 2006-2007 (unpublished manuscript, July 2007).

SPECIAL REPRESENTATIVE OF THE SECRETARY-GENERAL FOR CHILDREN AND ARMED CONFLICT; UNITED NATIONS CHILDREN'S FUND. Machel Study. 10-Year Strategic Review. Mapping Note: Justice Processes and Reconciliation (unpublished manuscript, July 2007).

THE HUMANITARIAN NEWS AND ANALYSIS SERVICE OF THE UN OFFICE FOR THE COORDINATION OF HUMANITARIAN AFFAIRS (IRIN) 'SIERRA LEONE: Civil society criticizes "vague" government plan for post-war reform', IRIN, 13 July 2005, http://www.un-ngls.org/ orf/cso/cso9/sierra-leone.htm. (accessed on November 5, 2013).

UNICEF INNOCENTI RESEARCH CENTRE; THE INTERNATIONAL CENTER FOR TRANSITIONAL JUSTICE. Children and Truth Commissions. Florence: UNICEF, 2010.

WALZER, Michael. Spheres of Justice: A Defense of Pluralism and Equality. New York: Basic Books, 1983.

WESSELLS, Michael. Child Soldiers: From Violence to Protection. Cambridge: Harvard University Press, 2006.

ZIEGLER, Kai Peter. Democratic Republic of the Congo: The Transitional Constitution of April 1, 2003. International Journal of Constitutional Law vol. 3 number 4, p. 662-673, October 2005. 


\section{SELECT DOCUMENTS}

Agreement on the Establishment of a Special Court for Sierra Leone, adopted 16 January 2002, came into force on April 12, 2002, 2178 UNTS 137.

Convention on the Rights of the Child, adopted on November 20,1989, came into force on September 2, 1990, 1577 UNTS 3.

INTERNATIONAL CRIMINAL COURT NETWORK. Final Narrative Report: The International Criminal Court \& the Arab World. Amman, Jordan (February 14-16 ' 2005) http://www.icln. net/documents/Narrative\%20Report.pdf (accessed on June 10, 2012).

Optional Protocol to the Convention on the Rights of the Child on the Involvement of Children in Armed Conflict, adopted on May 25, 2000, came into force on February 12, 2002, 2173 UNTS 222.

SPECIAL REPRESENTATIVE OF THE SECRETARY-GENERAL FOR CHILDREN AND ARMED CONFLICT. Report of the Special Representative of the Secretary-General for Children and Armed Conflict (S/2005/72 [2005]) (unpublished document, July 2007).

Rome Statute of the International Criminal Court, adopted on July 17, 1998, came into force on July 1, 2002, 2187 UNTS 90 (Rome Statute).

UNITED NATIONS GENERAL ASSEMBLY Promotion and Protection of the Rights of Children. Impact of Armed Conflict on Children (August 26, 1996) UN Doc A/51/306.

UNITED NATIONS SECURITY COUNCIL Res 1612 on Children and Armed Conflict (S/RES/1612 [2005]).

UNITED NATIONS SECURITY COUNCIL Res 1379 on Children and Armed Conflict (S/RES/1379 [2001]).

UNITED NATIONS SECURTIY COUNCIL Res 1314 on Children and Armed Conflict (S/RES/1314 [2000]).

Received on: November 2014

Approved in: April 2015 